\title{
religion

\section{Girls by the Church: Construction of a Pussy Riot Event in Finland as a Threat to Russian Gender Roles and Sexual Norms}

\author{
TEIVo TEIVAINEN*
}

\begin{abstract}
In August 2012, pro-Kremlin media in Russia reported widely about an alleged attempt to replay the Pussy Riot stunt at an Orthodox cathedral in Finland. According to the reports, also reproduced by the Russian Foreign Ministry, a Finnish professor was facing several years' prison sentence in Finnish courts for having attacked the cathedral, carried urine containers, spread homosexual propaganda and committed various acts of blasphemy. Even if the Finnish media, eyewitnesses and state authorities repeatedly denied the claims, the story became a useful way for pro-Kremlin forces to normalise the Pussy Riot trial in Russia. The episode was an example of the recent politicisation of religion, gender and sexuality in the Russian public sphere.
\end{abstract}

\section{Keywords}

Pussy Riot; Orthodox Church; transnational activism; media.

\section{Author affiliation}

Teivo Teivainen is Professor of World Politics, Department of Political and Economic Studies at the University of Helsinki, Finland.

\footnotetext{
*Correspondence: Department of Political and Economic Studies, Unioninkatu 37, POB 54, 00014 University of Helsinki. E-mail: teivo.teivainen@helsinki.fi. 
In the beginning of August 2012, during the Pussy Riot trial, a Finnish professor of world politics organised a World Political City Walk in Helsinki as part of a festival about urban culture at Kiasma, the Finnish Museum of Contemporary Art. One of the stops of the walk took place in front of the Orthodox Cathedral of Helsinki where two female artists, dressed up in Pussy Riot styled bright clothes and balaclavas, calmly expressed solidarity with the imprisoned artists in Russia. The short stop resulted in a massive media campaign in Russia, in which the organiser of the walk, branded as 'Pussy Professor', was accused of having stormed the church and committed various acts of blasphemy, including spilling a 'jerry canister of urine' inside the church.

In Finland the media, authorities and eyewitnesses constantly denied any act of blasphemy, entering the church, or existence of urine containers, but the misinformation campaign escalated in Russia, culminating on 17 August 2012 when the Pussy Riot performers were given two-year sentences in a Russian court. After the main Russian TV channels 1 and 3 analysed the sentences of the Pussy Riot performers, they reported on a several years' jail sentence that 'Pussy Professor Teivainen' was about to receive in Finland for a similar act.

Even if in social and cultural research the researcher is often somehow involved in the object of study, this case involved me in an exceptionally direct way. As I was actively analysing the process during its peak through various kinds of media, it became a more intense personal experience in 'double hermeneutic' than any previous participatory project I had engaged with. This essay can be seen as a personal attempt to highlight some aspects that may have relevance for understanding some of the more general trends taking place in Russia.

The episode was one example of the recent politicisation of religion, gender and sexuality in the Russian public sphere. Even if the identity of the two performers in Helsinki was never made public, their apparently female bodies were used to make claims about the performance as a threat to traditional Russian values. Over several weeks various Russian media constructed a story of a scandalous gay professor who was insulting the orthodox religion and core family values by obligating young girls to shout homosexual slogans. The assumptions about my sexual identity were first constructed by referring correctly to my participation in various gay pride marches. Thereafter, my assumed homosexuality was framed as a threat to traditional Russian values.

As it was falsely claimed that I was prosecuted and that the Finnish police had detained me, ${ }^{1}$ the story was used by the Russian media and the Russian Foreign Ministry to normalise the sentence the Russian Pussy Riot performers were facing. The key message of the Russian authorities was that if even in Finland such acts of blasphemy lead to criminal prosecution, it was certainly not true that Russia would have turned its back to international rule of law standards by sentencing the Pussy Riot performers to prison. The other dimension of the story was that it was an example of how Western 'liberal' forces were staging a constant attack on the Russian religious order and gender values.

One of the few Russian newspapers that analysed the process without reproducing the pro-Kremlin misinformation campaign was St Petersburg Times

\footnotetext{
1 From Russian media these stories spread elsewhere, both by English-language Russian media such as Ria Novosti ('Finnish Professor Faces Charges for Pussy Riot-Style Stunt', 2012), and also by United Press International ('Man arrested in support of Pussy Riot', 2012).
} 
(Chernov 2012). It commented on the usefulness of the case for the Russian government's media strategy in the context of the Pussy Riot trial:

While international media reported on the trial, describing it as a 'medieval witch trial' and a 'farce,' and published images of the defendants sitting in a cage in the courtroom on their front pages, many Russian media were discussing the 'attempted blasphemy' in Helsinki, arguing that Pussy Riot would also have faced a prison sentence in European countries for their punk prayer. Russia's Foreign Minister Sergei Lavrov went as far as to say, on August 20, that 'staging a blasphemous event in a church' was punishable by a two-year prison sentence in Finland.

The event by the Orthodox Cathedral lasted for approximately twenty minutes, during which the only words the performers once said through a megaphone were 'Free Pussy Riot'. I briefly analysed with the megaphone comments by the spokesperson of the Orthodox Church of Finland who had compared the insulting nature of the Pussy Riot act in Russia to 'if sexual minorities were to hold a political rally on the grave of [the Finnish national war hero] Mannerheim on an independence day'. I asked the participants to reflect on that comparison. During the walk, I had already commented to the dozens of participants that the Finnish Orthodox Church did not depend on the same ecclesiastic authorities as the Russian Orthodox Church, in order to avoid a simplistic identification between the two.

The cathedral in Helsinki had already been closed for two hours, as established by its normal schedule, and as far as I know nothing was happening inside it. $^{2}$ Nobody tried to force her or his way in. Nobody carried urine cans. Even if Finland still has somewhat archaic laws about blasphemy and breach of religious sanctity, they were not broken. The Finnish Orthodox Church representatives never complained about the activity. Standing peacefully with your face covered, as the two artists did, was by no means illegal either. ${ }^{3}$ Contrary to some claims in Russian media, the two performers were not my students.

The immediate feedback to the walk was overwhelmingly positive. The following couple of days I received various offers to repeat such walks (that included many other performances unrelated to Pussy Riot, see Museum of Contemporary Art 2012) in different places. Then, three days after the event, various media outlets in Russia started the campaign. The main source was a Finnish pro-Kremlin person called Johan Bäckman who over several years has been the most cited Finnish commentator in Russian media. He has taken the issues of gender and sexuality as key topics that express how Western activists and media attack Russian values. He has publicly called feminism 'a crime against humanity' and stated that the benign sentence of the Pussy Riot performers in Russia should be contrasted with other countries where they

\footnotetext{
2 In Russia one factor that probably contributed to the credibility of the allegation that the cathedral in Helsinki had to be closed down because of our 'attack' was that Russian churches do not routinely close so early.

3 The Detective Chief Inspector of the Helsinki Police officially stated in a police report on 31 August 2012 that there were no reasons to believe that any crime would have been committed by anyone participating in the event. No criminal investigation was ever opened. The police also declared that our actions 'did not violate what the orthodox religious teachings consider sacred' and that there was no intention to insult the orthodox religion. Helsingin poliisilaitos, tutkinnan päätös 8010/S/20698/12, 31.8.2012.
}

Religion and Gender vol. 4, no. 2 (2014), pp. 209-214 
would have received a 'well-deserved' death by hanging (Bäckman 2012). He has campaigned for Russian-style laws about prohibition of 'homosexual propaganda' to be established also in Finland. Widely discredited in Finland, in pro-Kremlin Russian media he is often portrayed as a 'human rights activist' (Chernov 2012).

I was extremely busy for the following weeks, trying to answer all the Russian journalists and others who called or sometimes flew over to interview me. The two performers, who did not want their identities to be disclosed, never spoke with the media after the event. In Finland and also in the betterinformed parts of the Russian media the campaign was mostly seen as a collection of politically motivated lies. ${ }^{4}$ More than once, it was clear that the Russian journalists who interviewed me were aware that much of the case was simply a hoax, but the resulting media reports in Russia kept to the story that the pro-Kremlin forces had started spinning. Some of the media in Russia later published corrections to their earlier articles and after a couple of weeks I received a personal apology letter from the editor-in-chief of Moscow Times. The University of Helsinki (2012) played an important role in correcting the errors in the Russian media. Much of the Kremlin-controlled big Russianlanguage media responded to the correction attempts with silence or headlines such as 'The Scandalous Finnish Professor is Accusing the Russian Media of Lying' (see Chernov 2012).

The 'jerry canister of urine' appeared in the stories a couple of days after the first media wave. Its apparent origins were in a small Finland-based Internet media outlet called Verkkomedia that often publishes stories based on proKremlin Russian media. The Finnish outlet mentioned the Russian news agency Interfax as its main source for the claim that we were carrying urine that we either tried to spill or did spill inside the church. When I asked the editor of the outlet to provide the sources, as no such information could be found in the available Interfax archives at the moment, he soon responded by stating that it had been a mistake and no such sources could be found. Even if he apologised for the occurrence and published a correction article the same day, after the brief appearance of the misinformation in the Finnish website the Russian media, including Interfax ('Finnish Professor Sued for Attempt to Replay Pussy Riot Stunt at Orthodox Cathedral in Helsinki' 2012), picked the urine story and started spinning it massively. The operation resembled a money-laundering technique in which the original source of the matter is made unclear.

The fabricated urine reference was a valuable resource for the Russian media, as it could highlight the undesirability of the alleged attack to the honour of religious and family values. In our case, an additional factor that increased the credibility of the urine reference was that in Russia there had been earlier and more reliable reports about urine being sprayed on the police by members of Voina, a radical art collective connected in various ways with Pussy Riot (Sturdee 2011).

The image of the Russian Mother, trying to defend her tradition and family, repeatedly appeared in the campaign around our activity, resembling the way the mother image has been used to discredit the Russian Pussy Riot performers (on the politics of profanation by Pussy Riot, see Prozorov 2013). In

4 Examples of a correct description of the event include Chernov 2012, Nieminen 2012 and Kniivilä 2012. 
a demonstration outside the Finnish embassy in Moscow in August 2012, my name appeared on placards that a small but vocal group of Russian mothers was carrying to protest against the alleged mistreatment of Russian families in Finland. Even if the main targets of the demonstration were the Finnish social security officers that allegedly were systematically taking babies away from Russian-speaking mothers in Finland and placing them in concentration-camp-like facilities, I was included in the black list they presented because by promoting homosexuality I was a 'threat to the Russian family'. In other statements, the alleged fact that I had forced two young women to take part in a blasphemous action was considered a misogynous attack on the female honour.

Apart from some wishes to 'rock [my] fascist ass' and demands to get a new picture of me for an Internet gallery of Russophobes, the personal correspondence I received from Russia was mostly supportive. In Finland, the claims about a supposed Russophobia were countered by referring to the suggestion I made during the same walk that Finnish schools should start teaching Cyrillic Alphabet (Teivainen 2013). The alleged Russophobia was, however, present in some Russian media, as feminism and gay rights could be portrayed as essentially anti-Russian themes.

The transnational diffusion of the story about me facing several years of prison was made possible by a strategic use of vague translations of legal terminology. The pro-Kremlin Finnish person mentioned above filed a report to the police in which it was claimed that I had broken various Finnish laws and committed an act of blasphemy. Even if the police soon communicated that there was no reason to open any investigation, the report itself, that any individual citizen is free to bring to the police, was reported in Russian media as showing that the state prosecutor was demanding a harsh sentence for me. One curious dimension of the report sent to the police by the Finnish pro-Kremlin operator was that it had a paragraph accusing me of spreading homosexual propaganda. As such propaganda would by no means be illegal in Finland, it was another sign of the target audience of the whole Finnish operation being elsewhere. The paragraph could be used to claim in Russia that the recent legal prohibitions of disseminating non-traditional sexual behaviour are not a breach of international standards, as even in the Pussy professor case in Finland promotion of homosexuality was part of the 'official' legal prosecution.

After the Pussy Riot trial was concluded in Russia, the media attention to our activity calmed down. The more general debates around gender roles and sexuality have thereafter become increasingly heated. One of the ways to understand the increasing insistence on family values is that over recent years the Russian government has felt a need to rely increasingly on defence of religious traditions in order to attract support from the more conservative areas of the Russian electorate, as significant sections of the urban middle classes have expressed criticism of its policies. The momentarily massive media attention to our performance in Helsinki can also be interpreted in that context, even if a full explanation should take into account more causal factors.

\section{References}

Bäckman, Johan. 2012. 'Värivallankumouksen loppu ja viimeinen värivallankumouksellinen' [End of the Colour Revolution and the Last Colour Revolutionary], Blog of

Religion and Gender vol. 4, no. 2 (2014), pp. 209-214 
Johan Bäckman, 18.8.2012, accessed 29 December 2013, http://kohudosentti.blogspot. fi/2012/08/varivallankumouksen-loppu-ja-viimeinen.html.

Chernov, Sergey. 2012. 'Finnish Kremlin Supporter Sparks Slander Scandal', St Petersburg Times 29.8.2012, accessed 29 December 2013, http://sptimes.ru/index.php?action id=2\&story_id=36107.

'Finnish Professor Faces Charges for Pussy Riot-Style Stunt', Ria Novosti 15.8.2012, accessed 29 December 2013, http://en.ria.ru/world/20120815/175235190.html.

'Finnish professor sued for attempt to replay Pussy Riot stunt at Orthodox cathedral in Helsinki', Interfax 15.8.2012, accessed 29 December 2013, http://www.interfaxreligion.com/?act=news\&div=9702.

Helsingin poliisilaitos. Tutkinnan päätös [Helsinki Police Office. End of Investigation] 8010/S/20698/12, 31.8.2012.

Kniivilä, Kalle, 2012. 'Finnish Fools and Muscovite Mudslingers', Finrosforum 16.8.2012, accessed 29 December 2013, http://finrosforum.wordpress.com/2012/08/16/finnishfools-and-muscovite-mudslingers/.

'Man Arrested in Support of Pussy Riot', United Press International 15.8.2012, accessed 29 December 2013, http://www.upi.com/Top_News/World-News/2012/08/15/Manarrested-in-support-of-Pussy-Riot/UPI-50731345055673/?spt=hs\&;or=tn.

Museum of Contemporary Art, 2012. 'World Political City Walk', accessed 29 December 2013, http://www.kiasma.fi/calendar/kiasmatheatre/urb12/programme/world-politicalcity-walk.

Nieminen, Tommi, 2012. 'Pussy Riot, the Professor, and Playing the Media Game', Helsingin Sanomat24.8.2012, accessed 29 December 2013, http://www.hs.fi/english/article/NEWS+ ANALYSIS+Pussy+Riot+the+professor+and+a+plain+red+herring+/1329104670372.

Prozorov, Sergei, 2013. 'Pussy Riot and the Politics of Profanation: Parody, Performativity, Veridiction', Political Studies (early view, 17 June), 1-18.

Sturdee, Nick, 2011. 'Don't Raise the Bridge: Voina, Russia's Art Terrorists', The Guardian, 12.4.2011, accessed 29 December 2013, http://www.theguardian.com/ artanddesign/2011/apr/12/voina-art-terrorism.

Teivainen, Teivo, 2013. 'Cyrillic Alphabet for Finnish Schools', Helsinki Times 3.5.2013, accessed 29 December 2013, http://www.helsinkitimes.fi/columns/columns/viewpoint/6159-cyrillicalphabet-for-finnish-schools.html.

University of Helsinki, 2012. 'The University Corrects Erroneous Information about Professor Teivainen' 21.8.2012, accessed 29 December 2013, http://www.helsinki.fi/ news/archive/8-2012/16-16-08-30.html. 